\title{
The Application of Cooperative Learning Model during Online Learning in the Pandemic Period
}

\author{
Tiodora Fermiska Silalahi ${ }^{1}$, Ahmad Fakhri Hutauruk ${ }^{2}$ \\ ${ }^{1}$ Lecturer in English Education Study Program, Universitas Simalungun, Indonesia \\ ${ }^{2}$ Lecturer in History Education Study Program, Universitas Simalungun, Indonesia \\ tiodorasilalahi2@gmail.com
}

\begin{abstract}
In improving the quality of school education and learning in the future, it is necessary to change the mindset that will be used as the basis for implementing a learning program. What's more in the co-19 pandemic period that requires students to be able to study at home without interacting in class for a while. In the past the learning process was conventional, namely face-to-face in class. But even then, most teaching processes are still dominated by teachers. As a result, teaching and learning activities place more emphasis on teaching and not on learning. Learning activities favor the interests of those who teach. Efforts for learning to be focused on students, it is necessary to apply a cooperative learning model which is a form of change in mindset in learning activities at school. However, during this pandemic, the next challenge is how the cooperative process can take place in the online learning process. The absence of a physical meetup becomes an obstacle that can be minimized by the adaptation of the teacher in the distance learning process. In this case the teacher no longer dominates the learning activities, but rather becomes the facilitator and mediator of the process. The cooperative learning model is designed by giving opportunities to students together to build their own knowledge.
\end{abstract}

Keywords

cooperative learning models, online learning, pandemic period

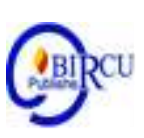

\section{Introduction}

2020 became the year that made human life in the world totally changed, the emergence of the corona virus that shook the world quickly became a global upheaval. The system of interaction between humans becomes changed with the existence of social distancing, the need to keep a distance in order to suppress the rate of spread of the virus. All fields have been affected, including education. Schools, which are the gathering place of people, inevitably become a region that is heavily affected must adapt to this pandemic. The pattern of teaching in the classroom also follows the government's recommendations that must be removed. While the material has not or cannot be completed if schools are closed. Distance learning or online can be a solution so that the discussion of the material continues even with online.

The old paradigm in the world of education regarding the learning process is based on John Locke's theory of tabularity which says that a child's mind is like a blank white paper that is clean and ready to wait for his teacher's scribbles. In other words, a child's brain is like an empty bottle that is ready to be filled with all the knowledge and wisdom of a teacher. Based on this assumption, many teachers carry out learning activities by transferring knowledge from teacher to student. The task of a teacher is to give and the task of a student is to receive. Besides that, the old paradigm view is that if someone has knowledge and expertise in a field, they will certainly be able to teach without knowing the 
ins and outs of true learning, but only need to pour what they know into empty bottles that are ready to be accommodated.

Today there are still teachers who embrace the old paradigm as the only alternative. They teach using the lecture method and are already framed on the material contained in the book and expect students to sit, be quiet, listen, take notes and memorize and pitting students against each other. In the case of learning, it is demanded that teachers must be able to relate past facts to present life. To be able to relate facts on the ground, teachers need to have a deep understanding of humanity, culture as a social heritage and social change that occurs in the social environment.

Certain online learning will be less meaningful without the synergy of appropriate learning strategies and methods. One application that can integrate online learning is cooperative learning. The main study of cooperative learning is that based on this there needs to be effective learning that can be applied to students to improve their competence. What's more the result of the impact of the Covid-19 pandemic that struck so that learning does not run optimally because they have to stay at home and keep a distance. So online learning by using a cooperative model is one solution to the problem at hand to answer this problem.

A teacher needs to make improvements, such as innovating in learning, especially the use of strategies and learning models to improve comprehension and efforts to raise awareness among students. Widja (1998: 11) states "discard teaching methods that prioritize memorization. The emphasis on more effective student involvement is a new style in the way of learning, therefore in the implementation of learning the teacher's strategy and the application of cooperative learning models are needed to achieve the learning objectives to be achieved.

According to Slavin (1995: 5) defines cooperative learning models as follows "Cooperative learning methods share the idea that students work together to learn and are responsible for their teammates learning as well as their own". This definition implies that in cooperative learning students learn together, contribute ideas and are responsible for the achievement of individual and group learning outcomes.

In addition, Artzt and Newman (1990: 448) express the definition of cooperative learning as follows: "Cooperative learning is an approach that involves a group of learners working together as a team to solve a problem, complete a task, or accomplish an objective goal". According to the definition of this definition, cooperative learning is an approach that includes small groups of students who work together as a team to solve problems, complete a task to achieve a goal together.

Through some of the definitions above it can be said that cooperative learning in learning emphasizes cooperation between students in groups. This is based on the idea that students find it easier to find and understand a concept of facts if they discuss the problem with each other. Members of a group in cooperative learning, usually consisting of four to six people, where group members are formed are heterogeneous based on differences in academic ability, religion, gender and ethnicity.

Following the instruction from the teacher, the students' activities in cooperative learning include being active, completing assignments in groups, giving an explanation to a group of friends, encouraging their group friends to participate actively, and discussing. In order for student activities to proceed well and smoothly special skills are needed, called cooperative skills. Cooperative skills can be developed by developing communication and division of tasks between group members. 


\section{Research Method}

The method used in this research is included in the literature study. The type of data collected in the form of secondary data related to the results of research from various articles, literature sources and documents related to the theme of online learning and cooperative learning models. This is in accordance with the statement of Zed (2014), where in library research, library search is not only for the initial steps of preparing a research framework but also at the same time utilizing library resources in obtaining research data. The data then collected, compiled, reviewed, analyzed, and concluded. So it is related to the research theme.

\section{Discussion}

\subsection{The Purpose of Cooperative Learning}

The development of cooperative learning aims to achieve learning outcomes, acceptance of diversity, and development of social skills. Each of these objectives can be explained as follows:

a. Achievement of Learning Outcomes

Although cooperative learning includes a variety of social goals, cooperative learning also aims to improve student performance on academic assignments. Haryono (1995: 86) argues that this model excels in helping students understand difficult concepts, especially in studying and analyzing events in their entirety by restructuring their knowledge and awareness. The developers of this model have shown that the cooperative reward structure model has improved student achievement in academic learning and changes in norms related to learning outcomes.

In addition, cooperative learning can benefit students who work together to complete academic tasks, both the lower and upper groups. Upper group students will be tutors for lower group students. In this tutorial process, upper group students will increase their academic ability because they provide services as tutors to peers who need deeper thought about the relationship of ideas contained in certain material.

b. Acceptance of Individual Differences

The second important effect of the cooperative learning model is broad acceptance of people who differ according to race, religion, culture, social level, abilities, and disabilities. Cooperative learning provides opportunities for students with different backgrounds and conditions to work interdependent on shared tasks and through the use of cooperative reward structures, and learn to respect one another.

c. Development of Social Skills

The third important goal of cooperative learning is to teach students the skills of collaboration and collaboration. This skill is very important to have in the community. Many adults work in organizations that are interdependent with each other in society despite their diverse cultures. Meanwhile many young people and adults still lack social skills. This situation is proven by how often a small dispute between individuals can lead to violence.

\subsection{Principles of Cooperative Learning}

According to Anita, Lie (2002: 51) that "in cooperative learning there are five principles adopted, namely the principle of active student learning, cooperative learning, participatory learning, reactive teaching and enjoyable learning". An explanation of each of the basic principles of the cooperative learning model is as follows: 


\section{a. Active Student Learning}

The learning process by using student-centered cooperative learning models, learning activities more dominantly carried out students, knowledge that is built and found is by learning together with group members until each student understands the learning material and ends by making group and individual reports. group activities very clearly the activities of students by working together, conducting discussions, expressing the ideas of each member and testing them together, students dig up all information related to the topics that are subject to group study and also discuss with other groups.

b. Cooperate Learning

The learning process is passed through working together in groups to build on the knowledge being learned. It is this learning principle that underlies the successful application of the cooperative learning model. All students are actively involved in groups to conduct discussions and solve problems, so new knowledge is formed from the results of their collaboration. It is believed that the knowledge gained through the findings of this collaboration will be of more permanent value in each student's understanding.

c. Participatory Learning

Through participatory learning students learn by doing something (learning by doing) together to find and build knowledge that is the purpose of learning. For example when groups solve problems in study groups, they do tests, try to prove from the theories being discussed together, then discuss with other study groups. During the discussion, each group presented the results of group work and each group was given the opportunity to express their opinions and criticize the opinions of other groups.

d. Reactive Teaching

To apply this cooperative learning model, the teacher needs to create the right strategy so that all students have high motivation to learn. Student motivation can be aroused if the teacher is able to create a learning atmosphere that is fun and interesting and can convince students of the benefits of this lesson for their future. If the teacher knows that the student feels bored, the teacher must immediately find a way to anticipate it.

e. Enjoyable Learning

One characteristic of learning that is widely embraced in the renewal of learning today is fun learning. Learning must run in a pleasant atmosphere, there is no longer a scary atmosphere for students or a stressed learning atmosphere. A pleasant learning atmosphere must start with the attitude and behavior of the teacher outside and inside the classroom. Teachers must have a friendly attitude with language speech that loves their students. The steps of the cooperative learning model will not be effective if the learning atmosphere is not pleasant.

\subsection{Elements of Cooperative Learning}

In cooperative learning, there are several elements that are interrelated with one another, such as: the existence of cooperation, heterogeneous group members, collaborative skills, and interdependence. Johnson \& Johnson (Lie, 1993: 32) states that there are five basic elements found in the structure of cooperative learning, which are as follows:

- Positive interdependence, group failure and success are the responsibility of each group member, therefore fellow group members must feel bound and dependent on each other positively.

- Individual responsibility, each group member is responsible for mastering subject matter, because the success of group learning is determined by how much individual learning outcomes contribute. 
- Face-to-face, interactions that occur through discussion will benefit all group members, because they take advantage of the strengths and fill the weaknesses of each group member.

- Communication between members, because in every face-to-face discussion occurs, the communication skills between group members is very important.

- Evaluation of group processes, the success of learning in groups is found by the process of group work. To find out the success of group work processes is done through evaluation of group processes.

\subsection{Strengths and Weaknesses of Cooperative Learning}

a. Strengths

Through Arends (1997: 118) in his research stated that none of the studies showed that cooperative learning had a negative influence. The findings of this study indicate that the use of existing models in cooperative learning has proven to be superior in improving student learning outcomes compared to the individual learning models used so far. Cooperative learning can cause psychological elements of students to become aroused and become more active. This is caused by a sense of togetherness in the group, so that they can easily communicate with simpler language. When discussing the memory function of students become more active, enthusiastic, and brave to express opinions. Cooperative learning can also increase the hard work of students, more active and motivated.

The greatest advantage of applying cooperative learning is seen when students apply it in completing complex tasks. In addition, it can also improve individual and group skills in solving problems, increase commitment, can eliminate prejudice against peers.

b. Weaknesses

In Slavin (1995) states that the shortcomings of cooperative learning are the contributions of low-achieving students, being less and students who have high achievements will lead to disappointment. This is caused by the role of smart group members who are more dominant. In addition to completing a subject matter with cooperative learning will take relatively longer than conventional learning, can even cause the material can not be adapted to the existing curriculum if the teacher has no experience. In terms of teaching skills, teachers need careful preparation and long experience to be able to apply cooperative learning well.

\subsection{Types Cooperative Learning Model}

According to Slavin (1995) there are seven types of cooperative learning models, namely:

- Students Teams-Achievement Division (STAD) Model

- Model Teams Games Tournaments (TGT)

- Team Assisted Individualization (TAI) Model

- Cooperative Integrated Reading and Composition (CIRC) Model

- Model Group Investigation (GI)

- JIGSAW Model

- CO-OPCO-OP Model

\subsection{Distance Learning (Online)}

Distance learning (online) has many advantages compared to face to face learning or conventional learning. What's more during the pandemic that requires to keep distance in accordance with health protocols echoed by the government. This is reinforced by the findings of Nisa's research (2012) which states that the average learning outcomes of 
English students in statistical courses taught by e-learning methods have better average learning outcomes than those taught by conventional methods. Allied with these results through Santoso research (2009) which states that online learning has a greater influence than learning by using textbooks on chemistry learning achievement. Likewise, the results of Mulyani's (2013) research showed that e-learning based learning influences the learning outcomes of physics on the concepts of impulse and momentum (student learning outcomes using e-learning learning are higher than using conventional learning or face to face.

There are quite a lot of choices for online learning applications that can be applied in the world of education. One of the free and familiar applications implemented is the Google Classroom application. Teachers, lecturers, tutors and instructors in general can open classes and invite students to the class. Online learning in the application can take place with various materials and assignments given by teachers to students. Teachers can also provide grades related to assignments that are collected neatly and well archived. The online learning that is applied allows teachers and students to carry out learning without going through face-to-face in the classroom by providing learning material (in the form of power point slides, e-books, learning videos etc., assignments (independent or group), as well as assessment. Teachers and participants students in this application it is possible to interact through discussion forums (streams) related to material issues and interactive learning paths.Even lately the Google Classroom application has included Google Meet in it which makes it possible to do Sabran and Sabara video teleconferences (2018) stated that google classroom learning as a learning medium as a whole was quite effective. Similar results obtained by Sari (2019) revealed that there was a significant influence of the ease, usefulness and quality of Google Classroom services on the effectiveness of learning and the success of learning outcomes.

Another application that can be used is Discourd. This application is almost the same as Google Classroom which has interesting features such as polling, gradebooks, files and links, quizzes, libraries, assignments, award badges, and parent code. The advantages of this application can be monitored by parents simultaneously. So it is very suitable for elementary to middle class students who need more control from teachers and parents. The effectiveness of research results on the use of discourses in learning was revealed by Suriadhi et al. (2014).

However, there are several obstacles faced when conducting online learning, especially internet access (data packages) and the instructors and students are not yet accustomed to using online learning applications. As revealed from the survey results Gunawan et al. (2020) The most common obstacles encountered during the implementation of online learning are internet packages that are not owned by students, limited internet access by lecturers and students, and are not yet accustomed to online learning. Most lecturers conduct learning and discussion through socialmedia applications such as WhatsApp. Some use the online Moodle LMS developed by the university or independently or Google Classroom. Some online learning is also carried out through video conferencing by using the Zoom Cloud meetings application. Submission of material is mostly done by sharing files through WhatsApp messages and other social media. So that it becomes a buildup in Mobile memory. Which makes the ability of mobile phones become problematic because of the full memory quota.

Online learning from the findings above shows that there are still unfamiliar educators and students with a variety of available platforms. So that more access to online learning with WhatsApp media because this is what is used. This case is certainly a recommendation for every educator and student to start adaptive and continue to race to 
learn in accessing available online learning platforms so that the learning process is optimal so that the learning outcomes achieved by students can also be max. Even on the Youtube site, there are many YouTubers who upload various procedures to become teachers and students on online or distance learning platforms.

The most important thing in applying online learning to students should pay attention to various aspects so that learning objectives are achieved. Learning through this online network system as stated by Setyosari (2007) includes five important things, namely: (1) the content presented has relevance to the specific learning objectives to be achieved, (2) using learning methods through examples and exercises- exercises to help learners learn, (3) use media such as pictures and words to present content and methods, and (4) develop and build new knowledge and skills according to individual goals and improvement

Obstacles and problems with internet and network access are certainly serious concerns for all parties and become a classic obstacle. Unequal internet network which is very strong in urban areas but weakens when in rural areas. Being a serious concern for the government to level it up. Starting from educational institutions, local and central government, teachers and parents, to provide adequate internet access services so that the online learning process runs optimally. No matter how good the online learning platform, but without the support of the internet network, the impact is certainly not optimal. Good news for several mobile operators has issued a special program due to Covid-19. Some providers free internet services for certain accesses, for example for educational sites. This step is a tangible manifestation that should be followed in providing internet network facilities by all parties and providing active services in responding to technical constraints experienced by consumers.

\subsection{The Application of Cooperative Learning Model during Online Learning in the Pandemic Period}

Online learning through the cooperative model is significantly effective in achieving spiritual attitudes, social attitudes, projects, products and student learning completeness through Noor, et al. (2017). Based on various research results described above online learning with a cooperative model. can be an alternative in optimizing learning especially in the midst of the Covid-19 pandemic. Through online learning with the cooperative model, students can learn through meaningful learning so that the knowledge and knowledge they have have meaning that can be utilized as their provisions to become problem solvers of the problems faced with positive collaboration. Where in the pandemic make students separate from each other and connect in cyberspace only. Impasse in dealing with character learning that is cooperation can use this learning model as a solution.

\section{Conclusion}

The application of cooperative learning in learning places more emphasis on cooperation between students in groups. This is based on the idea that students find it easier to understand and understand a concept of facts if they discuss the problem with each other. In cooperative learning, students have good behavior, because they are motivated to learn and actively engage in various activities. To ensure that students will use time effectively and direct their energy toward productive activities, teacher creativity is needed in the process of learning activities. Online learning systems through cooperative models can provide many opportunities to access teaching materials by learning citizens. Many online platforms and media can be accessed via the internet by teachers and 
students. Some things that become obstacles in the implementation of online learning include limited internet quota and the unfamiliar teaching staff and students in applying it and then uneven internet network. So in this case there is a need for more special efforts to address this problem from all parties. One learning approach that can optimize online learning through cooperative models. This learning can facilitate students to learn concepts in depth and can improve learning outcomes through positive collaboration between students.

\section{References}

Anita, Lie. 2002. Cooperative Learning : Mempraktekan Cooperative Learning Di RuangRuang Kelas. Jakarta : PT. Gramedia Widiasarana Indonesia.

Arends. 1997. Classroom Instruction and Management. New York : MacGraw-Hill Companies. Inc.

Artzt, A.F. \& Newman. 1990. Cooperative Learning. Mathematics Teacher : Learning Publications.

Chasanah, ARU, Khoiri,N. \& Nuroso, H. (2016). Efektivitas Model Project Based Learning terhadap Keterampilan Proses Sains dan Kemampuan Berpikir Kreatif Siswa pada Pokok Bahasan Kalor Kelas X SMAN 1 Wonosegoro Tahun Pelajaran 2014/2015. Jurnal Penelitian Pembelajaran Fisika. 7 (1), 19-24.

Gunawan, Suranti, NMY. \& Fathoroni (2020). Variations of Models and Learning Platforms for Prospective Teachers During the COVID-19 Pandemic Period. Indonesian Journal of Teacher Education. 1 (2), 61-70

Haryono. 1995. Mempelajari Secara Efektif. Jakarta : PT Pustaka Jaya.

Hermann, M., Pentek, T. \& Otto, B. (2016). Design Principles for Industrie 4.0 Scenarios. Presented at the 49th Hawaiian International Conference on Systems Science.

I Gede Widja. 1998. Dasar-Dasar Pengembangan Strategi serta Metode Pengajaran . Jakarta: Depdikbud.

Kagermann, H., Lukas, W.D. \& Wahlster, W. (2013). Final report: Recommendations for implementing the strategic initiative INDUSTRIE 4.0. Industrie 4.0 Working Group.

Molinda, M. (2005), Instructional Technology and Media for Learning New Jersey Colombus, Ohio

Mulyani, W. (2013). Pengaruh Pembelajaran Berbasis $\quad$ E-Learning terhadapHasilBelajar Siswa Kada Konsep Impuls dan Momentum.Skripsi.ProgramStudiPendidikanFisika FTK UIB Syarif Hidaytullah Jakarta.

Nisa, LC. (2002). Pengaruh Pembelajaran E- Learning Terhadap Hasil Belajar Mata Kuliah Statistics Mahasiswa Tadris Bahasa Inggris Fakultas Tarbiyah IAIN Walisongo. Jurnal Phenomenon 2(1), 7-26.

Noor, ME., Hardyanto, W \& Wibawanto, H. (2017). Penggunaan E-Learning dalam Pembelajaran Berbasis Proyek Negeri 1 Jepara. Innovative Journal of Curriculum and Educational Technology 6 (1), 17-26.

Sabran \& Sabara, E. (2018). Keefektifan Google Classroom sebagai Media Pembelajaran. Prosiding Seminar Nasional Lembaga Penelitian Universitas Negeri Makassar "Diseminasi Hasil Penelitian Melalui Optimalisasi Sinta dan Hak Kekayaan Intelektual", 122-125

Sahin, A. (2013). STEM Project-Based Learning.Boston, USA: SensePublishers.

Santoso, E. (2009). Pengaruh Pembelajaran Daring Terhadap Prestasi Belajar Kimia Ditinjau Dari Kemampuan Awal Siswa. Tesis. Program Pasca Sarjana Universitas 
Sebelas Maret Surakarta.

Sari,IN.(2019).Pengaruh Penggunaan Googleclassroom terhadap Efektivitas

Pembelajaran Mahasiswa Universitas Islam Indonesia. Skripsi.Fakultas Ekonomi Universitas Islam Indonesia Yogyakarta.

Setyosari,P. (2007). Pembelajaran SistemDaring:TantangandanRangsangan.Majalah Ilmiah Pembelajaran 2, 1-10.

Slavin. R.E. 1995. Cooperative Learning : Theory, Research, and Practice.Boston : Allyn and Bacon

Suriadhi, Gede,. Tastra, I Dewa Kade. \& Suwatra,Ign.Wayan. (2014). PengembanganELearningBerbasis Edmodopada Mata Pelajaran IPA Kelas VIII di SMP Negeri 2 Singaraja. Journal Edutech Universitas Pendidikan Ganesha, 2(1).

Zed, M. (2014). Metode Penelitian Kepustakaan.Jakarta: Yayasan Obor Indo 